\title{
Change of Antibacterial Activity with Oxidation of ZnS Powder
}

\author{
Osamu YAMAMOTO, Jun SAWAI, Naomasa ISHIMURA, Hiromitsu KOJIMA and Tadashi SASAMOTO \\ Department of Applied Chemistry, Kanagawa Institute of Technology, 1030, Shimo-ogino, Atsugi-shi 243-0292
}

\author{
硫化亜鉛粉末の酸化に伴う抗菌活性の変化 \\ 山本 修・澤井 淳・石村真聖・小島博光・䈎本 忠 \\ 神奈川工科大学応用化学科, 243-0292 厚木市下荻野 1030
}

\begin{abstract}
The antibacterial activities of samples prepared from oxidation of $\mathrm{ZnS}$ powder were studied by measuring the change in electrical conductivity with the growth of Escherichia coli. Oxidation of ZnS occurred at above $550^{\circ} \mathrm{C}$ in air and then the amount of $\mathrm{ZnO}$ increased with increasing the oxidizing temperature. The obtained crystal structure of $\mathrm{ZnO}$ was a zinc-blende type. From results of antibacterial tests on $\mathrm{ZnS}$ powder samples before and after oxidation, the antibacterial activity was found to increase with increasing the oxidizing temperature. However, no activity of $\mathrm{ZnS}$ was observed, irrespective of the powder concentration. The $\mathrm{pH}$ value after dispersing the powder samples in physical saline solution was in the range between 5.5 and 8.0, increasing with the formation of $\mathrm{ZnO}$. [Received December 21, 1998; Accepted June 21, 1999]
\end{abstract}

Key-words : Zinc oxide, Zinc sulfide, Oxidation, Antibacterial activity, Conductance method

1. Introduction

Microbial pollution and contamination which took place by microorganisms, have been produced various problems in industrial and vital fields, such as degradation and infection, etc. In order to solve these problems, therefore, new sterilization and antibacterial techniques have been demanded and studied.1)-4)

Recently, the occurrence of antibacterial activity by using ceramic powders has been pointed out much attention as new technique substituting for conventional organic agents with the activity. ${ }^{5)-8)}$ On the ceramics powder with the activity, three ceramic powders of zinc oxide $(\mathrm{ZnO})$, calcium oxide $(\mathrm{CaO})$ and magnesium oxide $(\mathrm{MgO})$ were found to show a remarkable antibacterial activity. The use of three ceramics presented has the advantages following as; containing mineral element essential to human body, showing a strong activity in a small amount of ceramic powder and without the irradiation of light.9)-11) However, it was not clarified whether or not the oxygen in their ceramics is concerned as the chemical species on antibacterial activity.

In the case of $\mathrm{ZnO}$, the crystal structure and the electrical properties are similar to those on $\mathrm{ZnS}$. For example, $\mathrm{ZnO}$ and $\mathrm{ZnS}$ show the electrical conductivity of n-type and give the crystal structure of either wurtzite- or zincblende-type. Therefore, to use $\mathrm{ZnS}$ powder is essential to examine the contribution of oxygen in $\mathrm{ZnO}$ on antibacterial activity.

In the present work, the powder samples used in antibacterial tests were prepared with and without oxidizing $\mathrm{ZnS}$ at various temperatures in air. After preparing the slurries of the samples obtained, the evaluation of the antibacterial activity was carried out by measuring the change in electrical conductivity with the growth of Escherichia coli.

\section{Experimental}

2.1 Preparation of precursor samples and test bacteria

ZnS powder (purity: 99.99\%) was used as a starting material, which was shown in Fig. 1. ZnS powder with a particle size of approximately $0.5 \mu \mathrm{m}$ was heated at each temperature in air with the heating rate of $10^{\circ} \mathrm{C} / \mathrm{min}$. The sample powders heated were suspended with physiological saline in the concentration of 1.6 to $100 \mathrm{mg} / \mathrm{ml}$ and then the slurries prepared were used in antibacterial tests.

In order to know the crystal structure and the chemical composition of the powder samples prepared, X-ray diffraction measurement (XRD) and energy-dispersive X-ray measurement (EDX) was carried out, respectively. The thermal decomposition processes of $\mathrm{ZnS}$ were determined by termogravimetry-differential analysis (TG-DTA).

Escherichia coli 745 (E. coli) was used as a test bacterium and stored at Tokyo Metropolitan Research Laboratory of Public Health. E. coli was cultured in Brain Heat Infusion (BHI) broth at $37^{\circ} \mathrm{C}$ for $24 \mathrm{~h}$ on a reciprocal shaker. The bacterial culture was suspended in a sterile physiological saline with a final concel tration of approximately $10^{3}$ $\mathrm{CFU} / \mathrm{ml}$.

2.2 Test of antibacterial activity

The evaluation of the antibacterial activity of powder samples was carried out by measuring the change in electrical conductivity with the growth of $E$. coli (conductance method). Bactometer microbial monitoring system model 64 was used as the apparatus for measuring the conductivity. The preparation of bacteria into the wells of a module for the Bactometer was carried out following as; adding the sample slurries into the well containing modified plate count ager (MPCA) and then dispensing the bacterial suspension into the well. After setting the module in Bac-

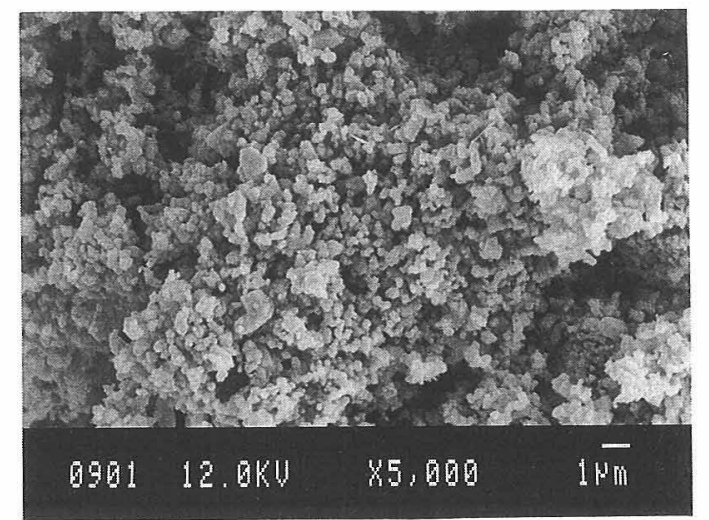

Fig. 1. SEM micrograph of $\mathrm{ZnS}$ powder used in antibacterial tests. 
tometer, the change of electrical conductivity was monitored during incubation at $37^{\circ} \mathrm{C}$ for $20 \mathrm{~h}$ in dark place. These procedures were reported in detail. ${ }^{10)}$

In order to examine indirectly the $\mathrm{pH}$ values when the sample slurries were added into the well, the powder samples with and without oxidation were dispersed into physiological saline with the powder concentration of 0.3 to $5.0 \mathrm{mg} / \mathrm{ml}$. After keeping the dispersed solutions for $24 \mathrm{~h}$, the $\mathrm{pH}$ values of solutions were measured.

\section{Results and discussion}

\subsection{Thermal decomposition of $\mathrm{ZnS}$}

The thermal decomposition of $\mathrm{ZnS}$ was measured by TG-DTA with the heating rate of $10^{\circ} \mathrm{C} / \mathrm{min}$ and shown in Fig. 2. An exothermic peak with weight loss was observed at $660^{\circ} \mathrm{C}$, starting at $550^{\circ} \mathrm{C}$ and ending at $700^{\circ} \mathrm{C}$, and also a slight weight loss without endo- and exo-thermic peaks was confirmed in the ranging from 700 to $830^{\circ} \mathrm{C}$. The overall weight loss of approximately $16.2 \%$ approached the theoretical one of $\mathrm{ZnO}$ produced due to the oxidation of $\mathrm{ZnS}$, which were in agreement with the results reported by Schultze et al. ${ }^{12)}$ And also, they discussed the oxidation process of $\mathrm{ZnS}$ by analyzing XRD patterns recorded in situ during the thermal oxidation. The overall reaction for thermal oxidation was written as followings:

$$
\begin{aligned}
& \mathrm{ZnS}+2 \mathrm{O}_{2} \longrightarrow \mathrm{ZnSO}_{4} \\
& 3 \mathrm{ZnSO} \mathrm{Zn}_{4} \longrightarrow \mathrm{Zn}_{3} \mathrm{O}\left(\mathrm{SO}_{4}\right)_{2}+\mathrm{SO}_{3} \\
& \mathrm{Zn}_{3} \mathrm{O}\left(\mathrm{SO}_{4}\right)_{2} \longrightarrow 3 \mathrm{ZnO}+2 \mathrm{SO}_{3}
\end{aligned}
$$

Assuming that the reactions (1) and (2) occurred in this study, the exothermal weight gain should be observed as addition of oxygen to $\mathrm{ZnS}$ yielding either $\mathrm{ZnSO}_{4}$ or $\mathrm{Zn}_{3} \mathrm{O}$ $\left(\mathrm{SO}_{4}\right)_{2}$. However, no weight gain was observed and also no diffraction peaks corresponding to $\mathrm{ZnSO}_{4}$ and $\mathrm{Zn}_{3} \mathrm{O}\left(\mathrm{SO}_{4}\right)_{2}$ were detected from the results of XRD measurement described below. From the result described above, it was suggested that the oxidation of $\mathrm{ZnS}$ without their intermediates started rapidly at $550^{\circ} \mathrm{C}$.

In Fig. 3, XRD patterns are shown on the samples oxidized at each temperature in air. Below the oxidizing temperature of $400^{\circ} \mathrm{C}$, only diffraction peaks corresponding to $\mathrm{ZnS}$ gave only. By the oxidation of $600^{\circ} \mathrm{C}$, however, small peaks corresponding to $\mathrm{ZnO}$ were detected in addition to those of $\mathrm{ZnS}$, suggesting the oxidation of small amount of $\mathrm{ZnS}$. At $900^{\circ} \mathrm{C}$, the peaks of $\mathrm{ZnS}$ were observed slightly and the diffraction intensity of $\mathrm{ZnO}$ became strongly. It may suggest the formation of large amount of $\mathrm{ZnO}$.

The chemical compositions of raw material $(\mathrm{ZnS})$ and

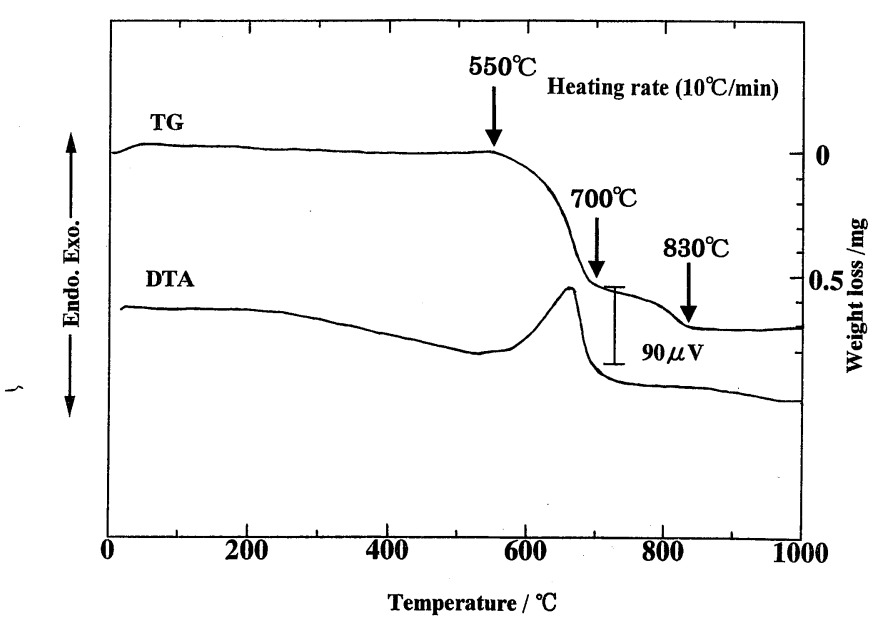

Fig. 2. TG-DTA curve of $\mathrm{ZnS}$ powder with the heating rate of $10^{\circ} \mathrm{C} / \mathrm{min}$.

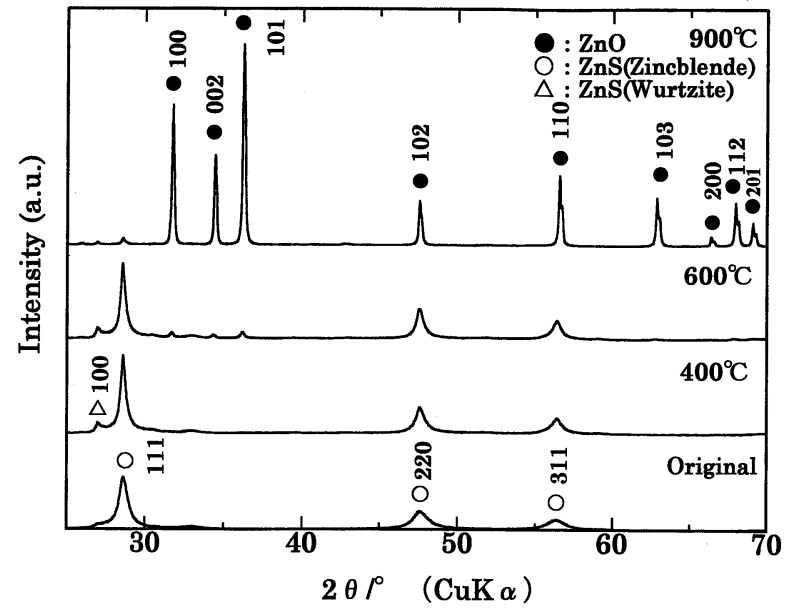

Fig. 3. XRD patterns of the samples oxidized at each temperature in air.

\begin{tabular}{|c|c|c|c|c|}
\hline \multirow{2}{*}{$\begin{array}{c}\text { element } \\
\text { (mol\%) }\end{array}$} & \multirow{2}{*}{$\mathrm{ZnS}$} & \multicolumn{3}{|c|}{ oxidizing temp. $\left({ }^{\circ} \mathrm{C}\right)$} \\
\hline & & 400 & 600 & 900 \\
\hline $\mathbf{S}$ & 40.49 & 42.10 & 39.32 & 3.74 \\
\hline $\mathrm{Zn}$ & 59.51 & 57.90 & 60.68 & 96.26 \\
\hline other & $\begin{array}{c}\text { not } \\
\text { detected }\end{array}$ & $\begin{array}{c}\text { not } \\
\text { detected }\end{array}$ & $\begin{array}{c}\text { not } \\
\text { detected }\end{array}$ & $\begin{array}{c}\text { not } \\
\text { detected }\end{array}$ \\
\hline
\end{tabular}

Table 1. Chemical Compositions of the Samples Oxidized at 400, 600 and $900^{\circ} \mathrm{C}$, and Together with $\mathrm{ZnS}$

the samples oxidized at the temperature ranging from 400 to $900^{\circ} \mathrm{C}$ were measured by $\mathrm{EDX}$ and summarized in Table 1. The concentration of sulfur in raw material was similar to those on the sample oxidized at $400^{\circ} \mathrm{C}$. At the oxidation above $600^{\circ} \mathrm{C}$, the concentration of sulfur in the samples decreased with the increase of the temperature, due to the oxidation of $\mathrm{ZnS}$. These results agreed with that of XRD measurement described above.

3.2 Change of electrical conductivity with bacterial growth

With the growth of bacteria, E. coli, it was known that the electrolytes such as organic acid and amino acid were produced with the digestion of proteins in medium. ${ }^{13)}$ The electrical conductivity in growth medium increases with the increase of the electrolytes produced. Therefore, it makes possible to evaluate the antibacterial activity. And also, the change of conductivity occurs when the bacterial concentration in medium reaches approximately $10^{7} \mathrm{CFU} / \mathrm{ml}$.

By using the powder samples of $\mathrm{ZnS}$ with and without oxidation, the evaluation of antibacterial activity was carried out by measuring the electrical conductivity with the growth of $E$. coli.

Figures 4(a), (b), (c) and (d) show the change of electrical conductivity in the case of $\mathrm{ZnS}$ and the sample heated at either 400,600 or $900^{\circ} \mathrm{C}$, respectively. In these figures, the incubation time to detect the change is called, "Detection Time," DT. Hence, if the value of DT is delayed by adding the powder samples, it can be distinguished that the samples have the effect of a growth inhibition on the bacteria. In the case of $\mathrm{ZnS}$ powder, the DT value was approximately $8 \mathrm{~h}$, irrespective of the powder concentration. As the value was comparable with that without the addition of powder samples, no antibacterial activity of $\mathrm{ZnS}$ was found in the powder concentration ranging from 1.6 to 100 

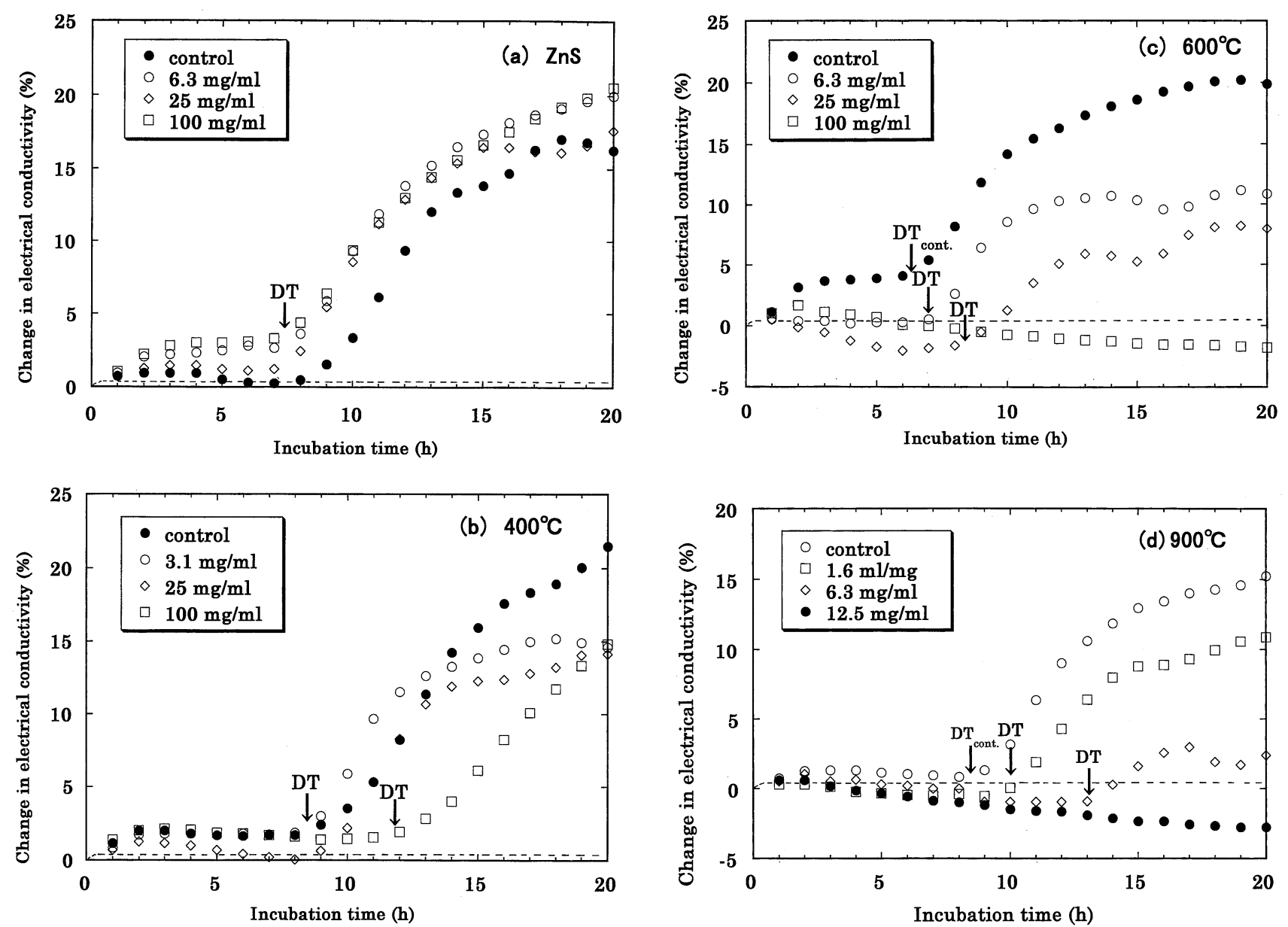

Fig. 4. The change in electrical conductivity of the samples against $E$. coli:

(a) $\mathrm{ZnS}$ powder, the powder sample oxidized at (b) 400 , (c) 600 and (d) $900^{\circ} \mathrm{C}$.

Broken line means the change in electrical conductivity of the samples in the case of the absence of $E$. coli.

$\mathrm{mg} / \mathrm{ml}$. On the other hand, the DT value of sample oxidized at either 400,600 or $900^{\circ} \mathrm{C}$ increased with the increase of powder concentration and even the delay of the DT value was found with the increase of the oxidizing temperature. From these results, it was found that the antibacterial activity against $E$. coli increased with increasing the concentration of $\mathrm{ZnO}$.

3.3 Comparison of antibacterial activity

Figure 5 shows the comparison of antibacterial activity of three samples oxidized at 400,600 and $900^{\circ} \mathrm{C}$, and together with $\mathrm{ZnS}$. The vertical axis, "DT/DT $\mathrm{D}_{\text {cont., }}$ represents the ratio of the DT value at specified concentration of samples to that at no addition of samples (cont.). If the value of DT/ $\mathrm{DT}_{\text {cont. }}$ is changed with a steep rise at lower powder concentration, it can be evaluated to show a stronger antibacterial activity. As shown in Fig. $5, \mathrm{ZnS}$ showed a constant in the value of $\mathrm{DT} / \mathrm{DT}_{\text {cont. }}$. With the increase of the oxidizing temperature on $\mathrm{ZnS}$, the pronounced change of the value was found at lower powder concentration. In other words, it was clarified the oxidation of $\mathrm{ZnS}$ resulted in an effective antibacterial activity on $E$. coli.

The growth inhibition of bacteria by ceramic powders may be pointed out to be concerned with four factors following as; ${ }^{14)}$ (1) the metal ions eluted from ceramic powders, (2) the active oxygen generated from ceramic powders, (3) the effect of $\mathrm{pH}$ value in solution dispersing ceramic powder and (4) the mechanical destruction of cell membrane to be in contact with ceramic powders. However, Yamamoto et al. ${ }^{10)}$ and Sawai et al. ${ }^{15)}$ reported that no effect of metal ions

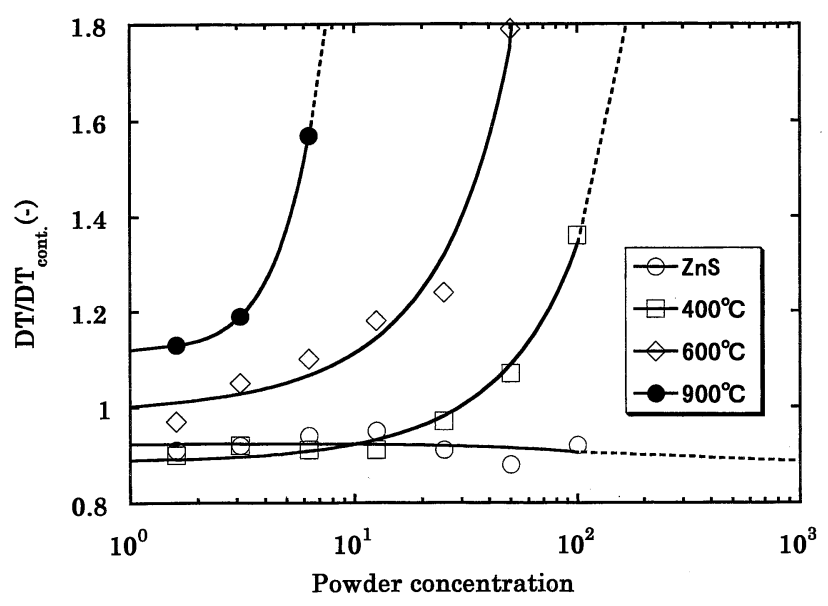

Fig. 5. Comparison of antibacterial activity against $E$. coli.

against antibacterial activity was observed. Therefore, we supposed that the appearance of activity is due to the mechanical destruction, $\mathrm{pH}$ value and the active oxygen.

As a first step, the mechanical destruction of cell membrane was measured by stirring a sterile physiological saline with a concentration of approximately $10^{3} \mathrm{CFU} / \mathrm{ml}$ dispersing $\mathrm{Al}_{2} \mathrm{O}_{3}$ powder (average particle size: $1.0 \mu \mathrm{m}$ ) without antibacterial activity, ${ }^{14)}$ the powder concentration of $\mathrm{Al}_{2} \mathrm{O}_{3}$ being $100 \mathrm{mg} / \mathrm{ml}$. In Fig. 6, survival ratio of $E$. coli 


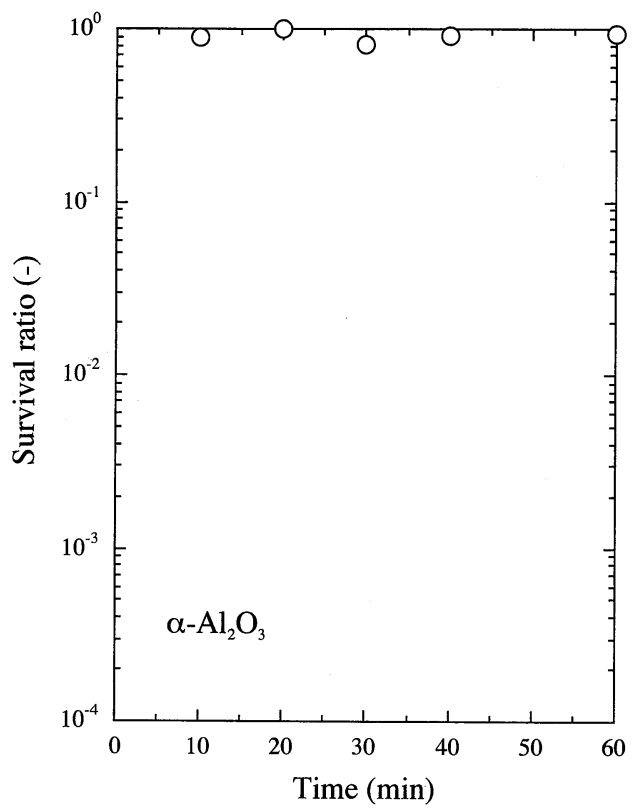

Fig. 6. Survival ratio of $E$. coli with stirring time; the used powder being $\mathrm{Al}_{2} \mathrm{O}_{3}$ with a particle size of $1 \mu \mathrm{m}$.

with stirring time at the rotation speed of $400 \mathrm{rpm}$ was shown. As shown in this figure, no survival ratio with rotation time during $1 \mathrm{~h}$ decreased, i.e., no bactericidal action by mechanical effect. This result suggests that no appearance of antibacterial activity is responsible for the mechanical destruction of cell membrane by ceramic powder.

The $\mathrm{pH}$ value in physiological saline dispersing $\mathrm{ZnO}$ powder has been known to be in the ranging from 7.0 to $\left.8.0,{ }^{6}\right)$ no appearance of the activity being observed in the $\mathrm{pH}$ region. In this study, $\mathrm{ZnS}$ powder with and without oxidation was used in antibacterial tests. Therefore, it is essential to examine the $\mathrm{pH}$ value in physiological saline dispersing powder samples. As a secondary step, the $\mathrm{pH}$ values in physiological saline dispersing powder samples were measured.

In Fig. 7, the values of $\mathrm{pH}$ in physiological saline were shown. In the case of the samples oxidized at above $600^{\circ} \mathrm{C}$, the values were detected in the range of 7.5 to 8.0 . However, $\mathrm{ZnS}$ and powder sample oxidized at $400^{\circ} \mathrm{C}$ showed the value of acidic region, suggesting the generation of sulfuric acid due to the elution of sulfur from the surface of sample powder. However, the $\mathrm{pH}$ value in the observed acidic region did not affect the bacterial growth.

From these results, it was supposed that the $\mathrm{pH}$ value and the mechanical effect did not affect antibacterial activity in all powder samples. The appearance of antibacterial activity of $\mathrm{ZnO}$ has been considered to be due to the generation of $\mathrm{H}_{2} \mathrm{O}_{2}$ from the surface of $\mathrm{ZnO}$ powder. ${ }^{6), 10), 15)}$ On the powder sample oxidized at $900^{\circ} \mathrm{C}$, hydrogen peroxide, $\mathrm{H}_{2} \mathrm{O}_{2}$, was measured with the same operation of previous paper. ${ }^{10)}$ $\mathrm{H}_{2} \mathrm{O}_{2}$ was detected in a concentration of $5 \mu \mathrm{g} / \mathrm{ml}$, when the powder concentration in physiological saline was 50 $\mathrm{mg} / \mathrm{ml}$. From the result and the reports, the increase in the antibacterial activity with the oxidation of $\mathrm{ZnS}$ seems to originate from the increase of $\mathrm{H}_{2} \mathrm{O}_{2}$ accompanied with increasing the amount of $\mathrm{ZnO}$.

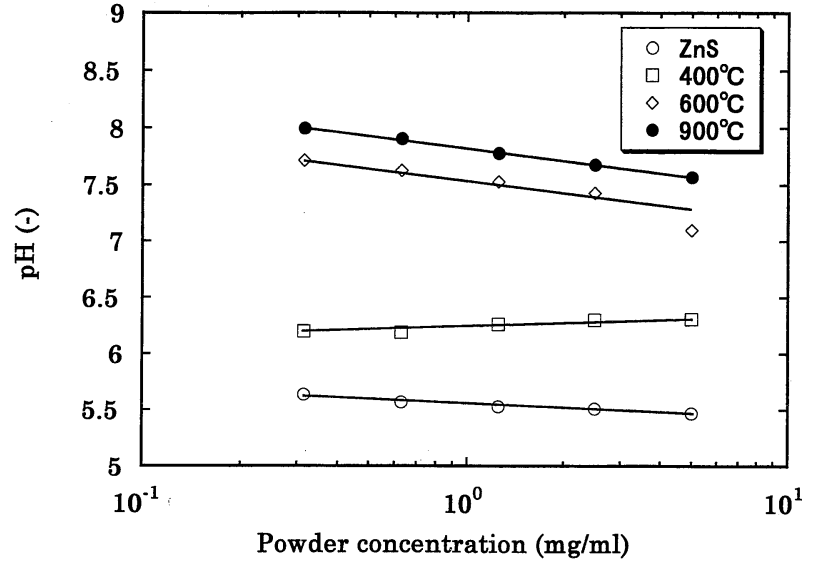

Fig. 7. The $\mathrm{pH}$ values in physiological saline dispersing the samples with and without oxidations.

\section{Conclusion}

By using the $\mathrm{ZnS}$ powder oxidized at various temperatures, the evaluation of the antibacterial activity was carried out by measuring the change in electrical conductivity with the growth of Escherichia coli. The following results were found.

The oxidation reaction of $\mathrm{ZnS}$ occurred above $550^{\circ} \mathrm{C}$ and then the concentration of sulfur in the samples decreased with the increase of the oxidizing temperature.

The antibacterial activity of the oxidized $\mathrm{ZnS}$ against Escherichia coli was found; the activity being shown in the increase of the powder concentration and the oxidizing temperature, i.e., increase of an amount of $\mathrm{ZnO}$. However, no antibacterial activity of $\mathrm{ZnS}$ without oxidation was detected.

References

1) T. Kusaka and Y. Takagi, J. Antibact. Antifung. Agents, 20, 451-57 (1992).

2) M. Saito, J. Antibact. Antifung. Agents, 21, 17-21 (1993).

3) Y. Tsunoda, H. Egawa and O. Yuge, J. Antibact. Antifung. Agents, 20, 571-75 (1992).

4) A. Oya, Fine Chemicals, 25, 5-12 (1996).

5) J. Sawai, H. Igarashi, A. Hashimoto, T. Kokugan and M. Shimizu, J. Chem. Eng. Jpn., 28, 288-93 (1995).

6) J. Sawai, E. Kawada, F. Kanou, H. Igarashi, A. Hashimoto, T. Kokugan and M. Shimizu, J. Chem. Eng. Jpn., 29, 251-56 (1996).

7) Y. Kurihara, New Ceramics, No. 7, 39-45 (1996).

8) T. Yamamoto, M. Uchida and Y. Kurihara, J. Antibact. Antifung. Agents, 19, 425-31 (1991).

9) J. Sawai, O. Yamamoto, M. Hotta, H. Kojima and T. Sasamoto, J. Chem. Soc. Jpn., 1998, No. 9, 633-36 (1998).

10) O. Yamamoto, M. Hotta, J. Sawai, T. Sasamoto and H. Kojima, J. Ceram. Soc. Japan, 106, 1007-11 (1998) [in Japanese].

11) O. Yamamoto, J. Sawai, M. Hotta, H. Kojima and T. Sasamoto, J. Ceram. Soc. Japan, 106, 1252-54 (1998) [in Japanese].

12) D. Schultze, U. Steinike, J. Kussin and U. Kretzschmar, Cryt. Res. Technol., 30, 553-58 (1995).

13) A Oya, T. Banse, F. Ohashi and S. Otani, Appl. Clay Sic., 6, 135-42 (1991).

14) J. Sawai, Doctoral Thesis, Tokyo University of Agriculture and Technology (1996).

15) J. Sawai, H. Kojima, H. Igarashi, A. Hashimoto, S. Shoji, T. Kokugan and M. Shimizu, J. Ferment. Bioeng., 86, 521-22 (1998). 